\title{
IMMEDIATE AND DELAYED SOLUBILITY OF MINERAL TRIOXIDE AGGREGATE AND PORTLAND CEMENT
}

\author{
Augusto BODANEZI ${ }^{1}$, Nara CARVALHO ${ }^{2}$, Daniela SILVA ${ }^{3}$, Norberti BERNARDINELI ${ }^{4}$, Clovis Monteiro BRAMANTE ${ }^{4}$, \\ Roberto Brandão GARCIA ${ }^{5}$, Ivaldo Gomes de MORAES ${ }^{5}$
}

\author{
1- DDS, MSc, PhD Student in Endodontics, Department of Operative Dentistry, Endodontics and Dental Materials, Bauru School of Dentistry, \\ University of São Paulo, Bauru, SP, Brazil. \\ 2- DDS, MSc in Endodontics, University of Uberlândia, Uberlândia, MG, Brazil. \\ 3- DDS, Resident in Endodontics, Hospital for Rehabilitation of Craniofacial Anomalies, University of São Paulo, Bauru, SP, Brazil. \\ 4- DDS, PhD, Chairman Professor of Endodontics, Department of Operative Dentistry, Endodontics and Dental Materials, Bauru School of \\ Dentistry, University of São Paulo, Bauru, SP, Brazil. \\ 5- DDS, PhD, Assistant Professor of Endodontics, Department of Operative Dentistry, Endodontics and Dental Materials, Bauru School of \\ Dentistry, University of São Paulo, Bauru, SP, Brazil.
}

Corresponding address: Prof. Dr. Norberti Bernardineli - Departamento de Dentística, Endodontia e Materiais Dentários, Faculdade de Odontologia de Bauru, Universidade de São Paulo. Alameda Dr. Octávio Pinheiro Brisolla 9-75, 17012-901, Bauru, SP, Brasil.

Phone: 5514 3235-8344. Fax: 5514 3224-2788 - e-mail: norberti@fob.usp.br

Received: May 21, 2007 - Modification: August 13, 2007 - Accepted: October 25, 2007

\begin{abstract}
$\Gamma_{\text {his }}$

his study investigated the solubility of mineral trioxide aggregate (MTA) and Portland cement since its mixture until 672 hours, by means of two complimentary methods. Metal ring molds filled with the cements were covered with distilled water and, at each experimental time (3, 24, 72, 168, 336 and 672 hours), were weighed as soon as the plates in which the samples have been placed. Empty rings served as the control group $(n=8)$. Mean weight gain and loss was determined and analyzed statistically by two-way ANOVA and Tukey's test for all pairwise comparisons. Only Portland cement showed less than 3\% weight loss through 24 hours. Detached MTA residues were heavier than those of Portland cement over the 3 to 168 hours. The weight of MTA rings increased more than that of Portland rings within 672 hours $(p=0.05)$. The findings of the present study indicate that, in an aqueous environment MTA is more soluble than Portland cement and exceeds the maximum weight loss considered acceptable by ISO 6876 standard (2001).
\end{abstract}

Key words: Solubility. MTA. Portland. Physical properties.

\section{INTRODUCTION}

Mineral trioxide aggregate (MTA) consists of a powder that, when added of water, forms a grainy and slurry mixture able to harden even in presence of complete humidity ${ }^{5,10,26,27,29}$. The biocompatibility ${ }^{16,17}$, dentinogenic activity $^{5,11,15}$ and sealing ability ${ }^{2,28,30}$ attributed to MTA are believed to depend entirely on the physicochemical interactions of the cement with the environment ${ }^{22}$.

After setting MTA hydration produces Portlandite, which is essentially considered crystalline calcium hydroxide ${ }^{5,9,24,25}$. Alkaline $\mathrm{pH}$ levels and calcium ions detected in the water surrounding MTA M $^{4,8,22}$ are considered essential to hard-tissue deposition ${ }^{22,26}$ and probably related to its dissolution in moist environment such as hard and soft tissues $^{9,22}$.

Recently, a white version of MTA, chemically similar to the grey version was introduced to the market ${ }^{18,4,24,25}$. The manufacturer claims that, differently from gray MTA, this form does not offer risks of tooth staining ${ }^{16}$ and gingival discoloration ${ }^{3}$ caused by iron diffusion to tissues and can applied as pulp capping material or perforation sealant in anterior teeth.

MTA has a prolonged setting time and is considered unstable when irrigated before complete hardening ${ }^{1,2,4,26}$. Until now, all studies on the solubility of mineral trioxide aggregate considered it less soluble than Portland cement and under the $3 \%$ maximum weight loss determined as acceptable by International Standard Organization ${ }^{12}$ after storage in distilled water for 24 hours ${ }^{9,13,6,21,26}$. However, these investigations have been conducted based on the decrease in the mass of hardened and dried specimens ${ }^{6,9,13,21,26}$, a circumstance completely different from that observed in oral tissues, where MTA is routinely used.

Although there may be a difference in particle uniformity, gypsum content and presence of radiopaque substance, 
the overall composition of MTA is similar to that of Portland cement $^{1,24,25}$. Therefore, this study tested the hypothesis that the solubility of MTA when completely covered by water since its mixture is presumed to follow a pattern similar to that of Portland over 672 hours.

\section{MATERIALAND METHODS}

The weight gain and loss of two commercially available materials, grey MTA ${ }^{\circledR}$ (Angelus, Londrina, PR, Brazil) and grey Portland cement (Votoran ${ }^{\circledR}$, Votorantin, São Paulo, SP, Brazil) supplemented with $20 \%$ bismuth oxide, was determined by the decline or increase in mass of specimens by storage in water. The weight of particles detached from the cements during the experiment was also recorded as recommended by the ISO 6876 standard $^{12}(2001)$.

\section{Preparation of Ring Samples}

Petri dishes and metal ring molds fixed to copper wires, having an internal diameter (i.d.) $20.0 \pm 0.1 \mathrm{~mm}$ and a height of $1.6 \pm 0.1 \mathrm{~mm}$, were cleaned in an ultrasound bath of detergent for 15 minutes before being weighed on a precision scale (accuracy: $0.0001 \mathrm{~g}$ ) alone or in sets consisting of one metal ring and one plate properly identified by codes. All weight measurements were made in grams and calculated to four decimal places.

The experimental cements were divided into portions of $1 \mathrm{~g}$ and mixed with $0.33 \mathrm{~mL}$ distilled water at a temperature of $25^{\circ} \mathrm{C}$ and relative humidity of $65 \pm 5 \%$ according to Friland and Rosado ${ }^{9}$ (2003). The mixture was homogenized for 30 seconds and each mould, positioned inside a glass plate, was filled with the experimental cements to slight excess using a spatula $(\mathrm{n}=8)$.

A single operator performed all manipulations and care was taken to prevent entrapment of air bubbles or leakage of the materials from the rings.

\section{Sample Weight}

The plate with the filled ring was weighed and $60 \mathrm{ml}$ distilled water, $\mathrm{pH} 7.1\left(37^{\circ} \mathrm{C}\right)$, was then spread with a LuerLock syringe over the plate distant from the ring so that the lower and upper surfaces of the cements were completely covered with fluid (100\% relative humidity). The sets were closed and placed in an oven at $37^{\circ} \mathrm{C}$ from which they were removed at the indicated intervals.

The control group consisted of empty rings. Eight molds were used for each experimental group and the test specimens were studied for up to 28 days. After 3, 24 72, 168, 336 and 672 hours of immersion, the rings were hanged over the Petri dish and gently irrigated on both sides to collect the residues released into the container. After superficial drying with absorbent paper, the rings were weighed and immediately placed on new previously weighed dishes filled with $60 \mathrm{~mL}$ bidistilled water.

The discarded plates were kept in the oven at $65^{\circ} \mathrm{C}$ for 24 hours for content dehydration and the mass of the residues released by the test specimens was determined. This process was repeated for each experimental period. The initial amount of cement inside the molds was determined by subtracting the weight of the ring-Petri dish from the weight of the filled ring-Petri dish. The weight gain or loss was recorded as the difference between the initial weight of rings and dishes and the final weight in each experimental time. The difference in mass was calculated as a percentage of the original weight of the cements. The weight gain and loss of the cements were analyzed by two-way analysis of variance and the comparison of the two methods as a function of time was performed by three-way ANOVA statistical test, both set at significance level of $5 \%$.

\section{RESULTS}

\section{Ring Weight Method}

There was no statistically significant change in the weight of the empty and MTA filled moulds after immersion in the distilled water through the experimental intervals. Portland specimens showed the heaviest weight in the 3rd hour and the lightest in 672 hours period $(\mathrm{p}=0.05)$.

During a setting time of 3 hours, Portland cement presented a weight gain of $0.98 \%$, statistically superior to $\operatorname{MTA}(0.32 \%)$ and to the control group. After 24 hours, there was a continuous weight gain of MTA rings statistically superior to Portland cement and empty rings in 168 hour time. In the 336th hour, Portland cement lost more weight $(0.24 \%)$ than MTA $(-0.08 \%)$. This difference, however, was not observed in the intervals to follow. Figure 1 shows the variations of weight gain and loss (\%) detected upon weighing of the rings during each experimental intervals.

\section{Residues Collection Weight Method}

During the 3-hour collection, both Portland (5.12\%) and MTA (4.23\%) plates were heavier than the control plates $(0.057 \%)$. A statistically significant decrease of Portland weight loss was detected from 3 to 24 hours, moment at which Portland group weight $(1.46 \%)$ was lower than that observed in MTA group (3.81\%) and higher than control $(0.053 \%)$, a behavior that was also observed within the $72-$ hour period (Portland: 1.67\%; MTA: 2.44\%; Control: 0.067\%). From the 168th hour on, the weight of residues detached from both cements was statistically equivalent and superior to that of the control group (Figure 2).

The residues collected on MTA plates in the first 24 hours were heavier than those collected in the 336- and 672hour periods, the latter being characterized by a weight loss of approximately $1 \%$ for both cements. There was no significant change in the weight of plates containing the empty ring moulds over the experimental intervals.

\section{Complementary Methods of Analysis}

Comparing the data of ring and dish weights of both cements as a function of cement type and time, statistically significant differences were detected $(\mathrm{p}=0.05)$ (Table 1$)$. 

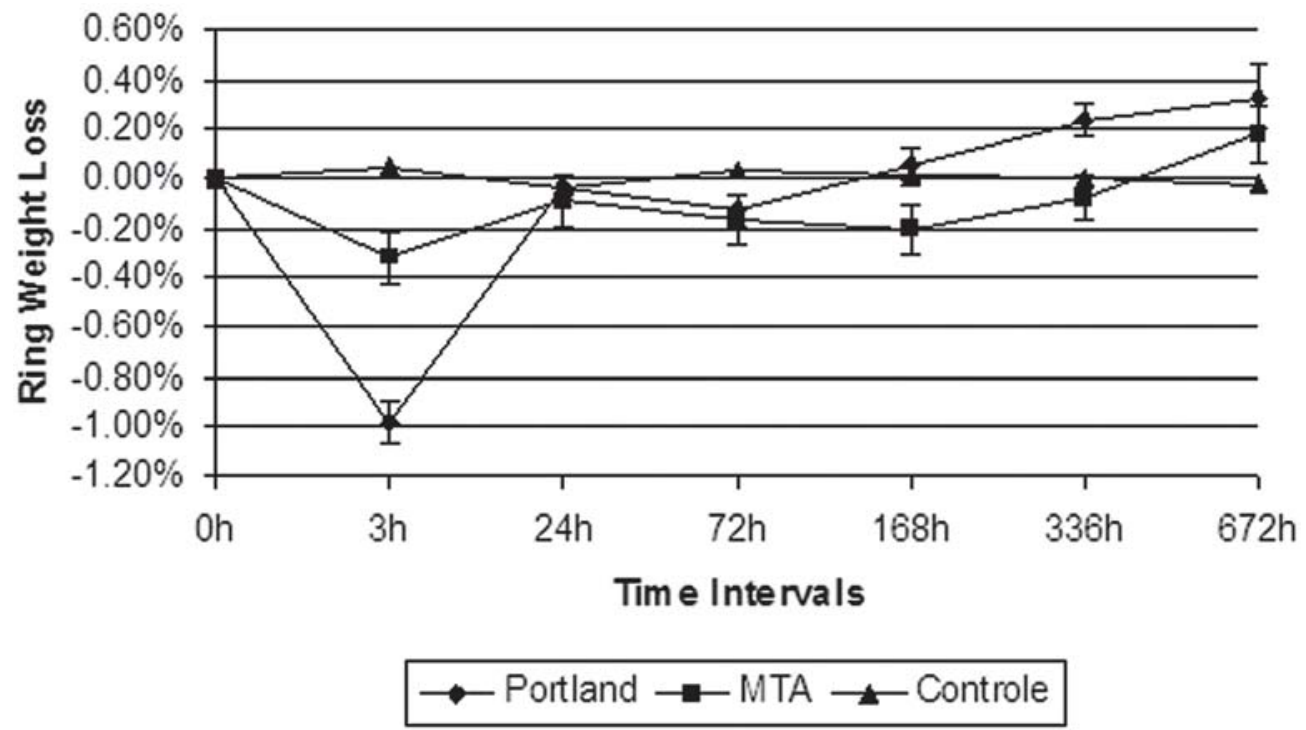

FIGURE 1- Mean weight loss \pm standard error of mean of the cements during the experimental intervals determined by the ring weight method
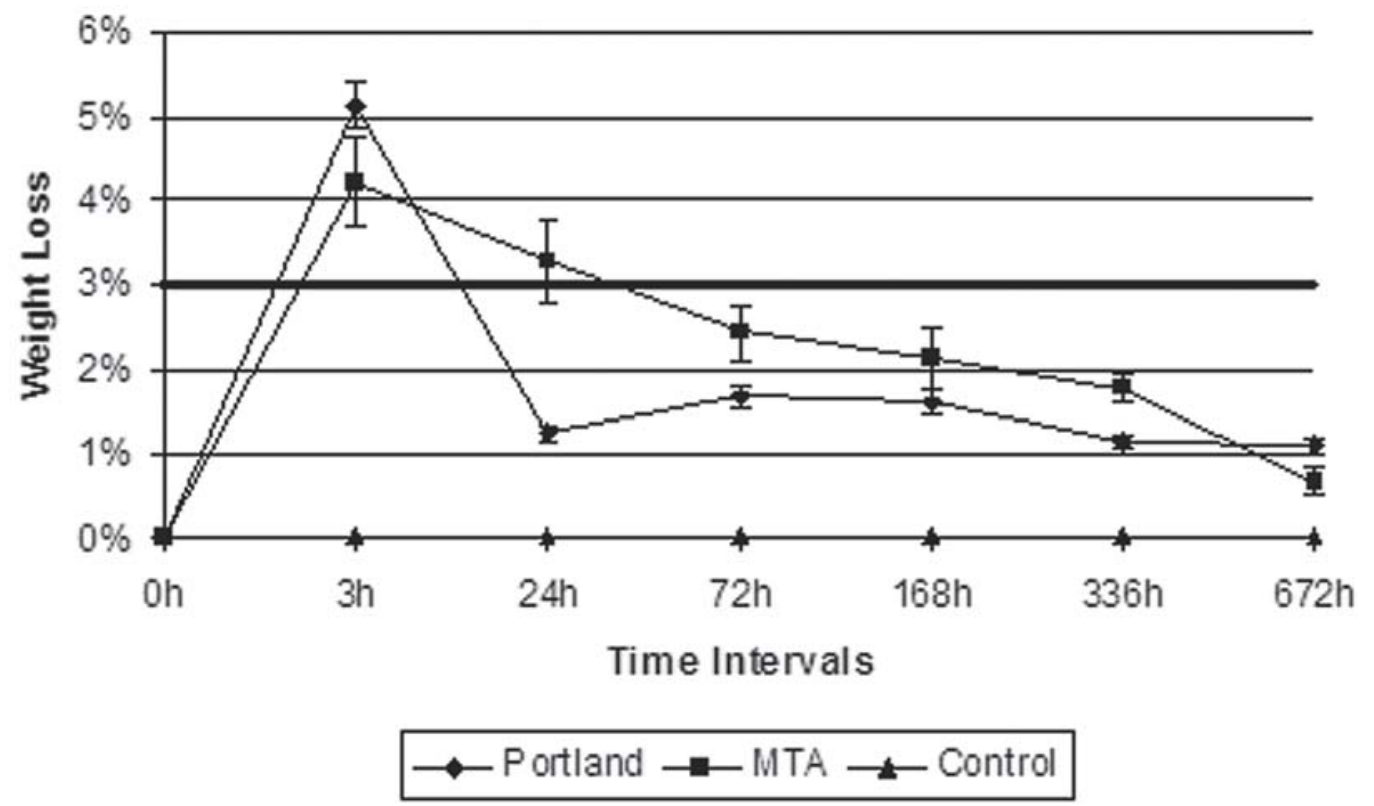

FIGURE 2- Mean weight loss \pm standard error of mean of the cements during the experimental intervals determined by the residue collection method. The bold horizontal line represents the requirement for compliance with the ISO 6876 standard (2001)

TABLE 1- Three-way ANOVA for the comparison between methods, cements and time ( $\mathrm{M}$ - methods; $\mathrm{C}$ - cements; Ti - Time; * statistically significant)

\begin{tabular}{lllllll}
\hline Effect & df Effect & MS Effect & df Error & MS Error & F & p value* $^{*}$ \\
\hline$M$ & 1 & 0.021240 & 30 & 0.000223 & 95.16363 & $0.000000^{*}$ \\
$\mathrm{C}$ & 2 & 0.001987 & 30 & 0.000233 & 8.90274 & $0.000922^{*}$ \\
$\mathrm{Ti}$ & 5 & 0.000071 & 150 & 0.000207 & 0.343510 & 0.885765 \\
$\mathrm{M}-\mathrm{C}$ & 2 & 0.004054 & 30 & 0.000223 & 18.16431 & $0.000007^{*}$ \\
$\mathrm{M}-\mathrm{Ti}$ & 5 & 0.002991 & 150 & 0.000207 & 14.42377 & $0.000000^{*}$ \\
$\mathrm{C}-\mathrm{Ti}$ & 10 & 0.000342 & 150 & 0.000207 & 1.648060 & 0.098290 \\
$\mathrm{M}-\mathrm{C}-\mathrm{Ti}$ & 10 & 0.001807 & 150 & 0.000207 & 8.71690 & $0.000000^{*}$ \\
\hline
\end{tabular}




\section{DISCUSSION}

It is well known that the humidity close to MTA determines the level at which its physical properties, such as sealing ability, push-out and flexural strength, are exerted ${ }^{10,29,30}$. Differently from previous solubility studies, in the present investigation, the cements were kept immersed since the moment of their mixture. The residue mass separated from MTA-Angelus was significantly higher than that of Portland cement and above the $3 \%$ maximum weight lost considered acceptable in the first 24 hours by the International Standard Organization ${ }^{12}$.

Ideally, a cement should block bacterial migration to pulpal and periodontal tissues to help controlling infection and preventing its recurrence. Solubility is a factor directly related to the sealing potential as well as dimensional changes. According to our results, the sealing ability of MTA in an aqueous environment might be compromised during the first 72 hours because of material's excessive solubility that may affect particle arrangement in dentinal cavity walls. Sluyk, et al. ${ }^{23}$ (1998) suggested that 3 days is the time needed for MTA to exert its good sealing ability when used as a perforation repair material.

Differently from MTA, the solubility of Portland cement decreased to $1.46 \%$ between 3 and 24 hours after collection (Figure 2). Interestingly, in vitro short-term studies have not detected differences in bacterial or dye microleakage when both materials were compared as root-end fillings or perforation repair material ${ }^{2,7}$. Nevertheless, the particular state of humidity in contact with specimens before and during the experimentations should be taken into account.

Clinically, the recommended provision of a wet cotton over MTA to assure proper setting and to accomplish best performance in the shortest period of time ${ }^{10,19,23,27,29}$ may favor the detachment of particles into pulpal and periodontal tissues and elicit inflammatory reaction. Holland, et al. ${ }^{11}$ (2001) noticed small particles of Portland cement in macrophage cytoplasm 60 days after pulpotomy and pulp capping in dog's teeth.

Additionally, when the dentist accidentally pushes freshly MTA out of root limits, the tissue humidity promotes a partial dissolution of the material that, according to our results, extends at least 28 days. The released particles into adjacent structures probably elicit an undesirable chronic inflammation processs ${ }^{11}$ and are also, perhaps, the cause of the dark discoloration of marginal gingiva described by Bortoluzzi, et al. ${ }^{3}$ (2007) when a root perforation was sealed with gray MTA.

The overall solubility of MTA or Portland cement by itself does not contraindicate its usage as root canal sealer or orthograde apical plug in cases where intracanal exudate would impair the setting process of conventional sealers. The behavior detected with MTA, specifically the excessive initial solubility followed by a constant decrease over 672 hours, have already been described to routinely used root canal sealers AH 26 and Tubli Seal ${ }^{14}$. Nevertheless, some adjustments to turn MTA easy to handle and be inserted adequately in the root canal are still necessary ${ }^{1,9,28}$.
The biological performance of MTA is attributed to its Portland content that throughout hydration is capable of releasing calcium and hydroxyl ions ${ }^{25}$. It has been reported that these ions are the main component detected on soluble and insoluble residues detached from MTA ${ }^{4,8,9,22,24}$. As ordinary Portland releases those ions in significantly higher quantities in the first 24 hours ${ }^{1,4,5}$ and considering that in this study the detachment of particles was more pronounced for MTA, it could be inferred that solubility is not the only phenomenon related to calcium and hydroxyl ions delivery in periodontal or pulp tissues.

Despite the hydration inherent pore formation, it is likely that the aqueous particle detachment also left empty spaces inside the cement matrix, which were ready to be filled by surrounding liquid. It is known that water uptake may compensate for dissolved material ${ }^{20}$ during weighing. In this way, the marked 3-hour increase in ring weight, more intense for Portland cement, may be an effect of initial water entrapment in the matrix structure. Liquid sorption may influence the interaction with an immediate covering material as seen during pulp capping. In a pilot study, the glassionomer applied over partially set MTA dissolved it, becoming thoroughly mixed with the material ${ }^{19}$.

After few hours, the hydration process promotes an increase in volume of solids and thus decreases the porosity of the paste ${ }^{5}$. Theoretically, a reduction of ring weight should be expected, a phenomenon observed at the 72nd and 168th hour, respectively, with Portland and MTA, extending until the end of the experiment (Figure 1).

In the development of Portland-derived cements, it should be considered that differences in particle uniformity and reduction of gypsum content cause a delayed reduction of cement solubility, described in this study, and also lengthening of setting as well as structure weakening, as reported elesewhere ${ }^{1,5,13}$

Before suggesting MTA as a restorative material ${ }^{1,2,10,29}$, studies addressing the reduction of initial solubility throughout addition of setting accelerants should be conducted to establish a possible correlation and assure invulnerability to bacterial microleakage. With regard to solubility, until its importance on cement's biocompatibility and long-term sealing property is not clarified, MTA should not be replaced by Portland cement in treatments where excessive moisture is present.

\section{CONCLUSION}

Based on the results of the present study, the null hypothesis should be rejected. MTA-Angelus was more soluble than Portland cement when completely immersed in an aqueous medium throughout 672 hours.

\section{ACKNOWLEDGEMENTS}

The authors wish to thank Dr. José Roberto Pereira Lauris for statistical advice and analysis of the results. 


\section{REFERENCES}

1- Ber BS, Hatton JF, Stewart GP. Chemical modification of ProRoot MTA to improve handling characteristics and decrease setting time. J Endod. 2007;33:1231-4.

2- Bortoluzzi EA, Broon NJ, Bramante CM, Garcia RB, Moraes IG, Bernardineli N. Sealing ability of MTA and radiopaque Portland cement with or without calcium chloride for root-end filling. J Endod. 2006;32:897-900.

3- Bortoluzzi EA, Araújo GS, Tanomaru JMG, Tanomaru-Filho M. Marginal gingival discoloration by gray MTA: a case report. J Endod. 2007;33:325-7

4- Bortoluzzi EA, Broon NJ, Duarte MAH, Demarchi ACCD, Bramante CM. The use of chloride as setting accelerator and its effect on $\mathrm{pH}$ and calcium ion release of mineral trioxide aggregate and white Portland cement. J Endod. 2006;32:1194-7.

5- Camilleri J. Hydration mechanisms of mineral trioxide aggregate. Int Endod J. 2007;40:462-70.

6- Danesch G, Dammaschke T, Gerth HUV, Zandbiglari T, Schäfer E. A comparative study of selected properties of ProRoot mineral trioxide aggregate and two Portland cements. Int Endod J. 2006;39:213-9

7- De-Deus G, Petrucceli V, Gurgel-Filho E, Coutinho-Filho T. MTA versus Portland cement as repair material for furcal perforations: a laboratory study using a polymicrobial leakage model. Int Endod J. 2006;39:293-8.

8- Duarte MAH, Demarchi ACC, Yamashita JC, Kuga MC, Fraga SC. $\mathrm{pH}$ and calcium ion release of 2 root-end filling materials. Oral Surg Oral Med Oral Pathol Oral Radiol Endod. 2003;95:345-7.

9- Friland M, Rosado R. Mineral trioxide aggregate (MTA) solubility and porosity with different water-to-powder ratios. J Endod. 2003;29:814-7

10 - Gancedo-Caravia L, Garcia-Barbero E. Influence of humidity and setting time on the push-out strength of mineral trioxide aggregate obturations. J Endod. 2006;32:894-6.

11 - Holland R, Souza V, Murata SS, Nery MJ, Bernabé PFE, Otoboni Filho JA. et al. Healing process of dog dental pulp after pulpotomy and pulp covering with mineral trioxide aggregate or Portland cement. Braz Dent J. 2001;12:109-13.

12- International Organization for Standardization (2001). International Standard ISO 6876: 2001: dental root canal sealing materials.

13- Islam I, Chng K, Jin Yap AU. Comparison of the physical and mechanical properties of MTA and Portland cement. J Endod. 2006;32:193-7.

14- Kaplan AE, Goldberg F, Artaza LP, De Silvio A, Macchi RL. Disintegration of endodontic cements in water. J Endod. 1997;23:43941.

15 - Menezes R, Bramante CM, Letra A, Carvalho VGG, Garcia RB. Histologic evaluation of pulpotomies in dog using two types of mineral trioxide aggregate and regular and white Portland cement as wound dressings. Oral Surg Oral Med Oral Pathol Oral Radiol Endod. 2004;98:376-9.

16- Moghaddame-Jafari S, Mantellini MG, Botero TM, McDonald NJ, Nör JE. Effect of ProRoot MTA on pulp cell apoptosis and proliferation in vitro. J Endod. 2005;31:387-91.
17- Morais CAH, Bernardineli N, Garcia RB, Duarte MAH, Guerisoli DMA. Evaluation of tissue response to MTA and Portland cement with iodoform. Oral Surg Oral Med Oral Pathol Oral Radiol Endod. 2006;102:417-21.

18 - MTA Branco. Cimento reparador: instruções de uso. Londrina: Angelus Soluções em Odontologia; 2004.)

19- Nandini S, Ballal S, Kandaswamy D. Influence of glass-ionomer cement on the interface and setting reaction of mineral trioxide aggregate when used as a furcal repair material using laser raman spectroscopic analysis. J Endod. 2007;33:167-72.

20 - Ørstavik D. Weight loss of endodontic sealers, cements and pastes in water. Scand J Dent Res. 1983;91:316-9.

21 - Poggio C, Lombardini M, Alessandro C, Simonetta R. Solubility of root-end-filling materials: a comparative study. J Endod. 2007;33:1094-7.

22- Sarkar NK, Caicedo R, Ritwik P, Moiseyeva R, Kawashima I. Physicochemical basis of the biologic properties of mineral trioxide aggregate. J Endod. 2005;31:97-100.

23- Sluyk SR, Moon PC, Hartwell GR. Evaluation of setting properties and retention characteristics of MTA when used as a furcation perforation repair material. J Endod. 1998;24:768-71.

24- Song J, Mante FK, Romanow WJ, Kim S. Chemical analysis of powder and set forms of Portland cement, gray ProRoot MTA, white ProRoot MTA, and gray MTA-Angelus. Oral Surg Oral Med Oral Pathol Oral Radiol Endod. 2006;102:809-15.

25 - Tay FR, Pashley DH, Rueggeberg FA, Loushine RJ, Weller RN. Calcium phosphate phase transformation produced by the interaction of the Portland cement component of white mineral trioxide aggregate with a phosphate-containing fluid. J Endod. 2007;33:9447.

26- Torabinejad M, Hong CU, McDonald F, Pitt Ford TR. Physical and chemical properties of a new root-end filling material. J Endod. 1995;21:349-53.

27- Torabinejad M, Chivian N. Clinical applications of mineral trioxide aggregate. J Endod. 1999;25:197-205.

28- Vizgirda PJ, Liewehr FR, Patton WR, McPherson JC, Buxton TB. A comparison of laterally condensed gutta-percha, thermoplasticized gutta-percha, and mineral trioxide aggregate as root canal filling materials. J Endod. 2004;30:103-6.

29- Walker MP, Diliberto A, Lee C. Effect of setting conditions on mineral trioxide aggregate flexural strength. J Endod. 2006;32:3346.

30- Wu M, Kontakotis EG, Wesselink PR. Long-term seal provided by some root-end filling materials. J Endod. 1998;24:557-60. 